
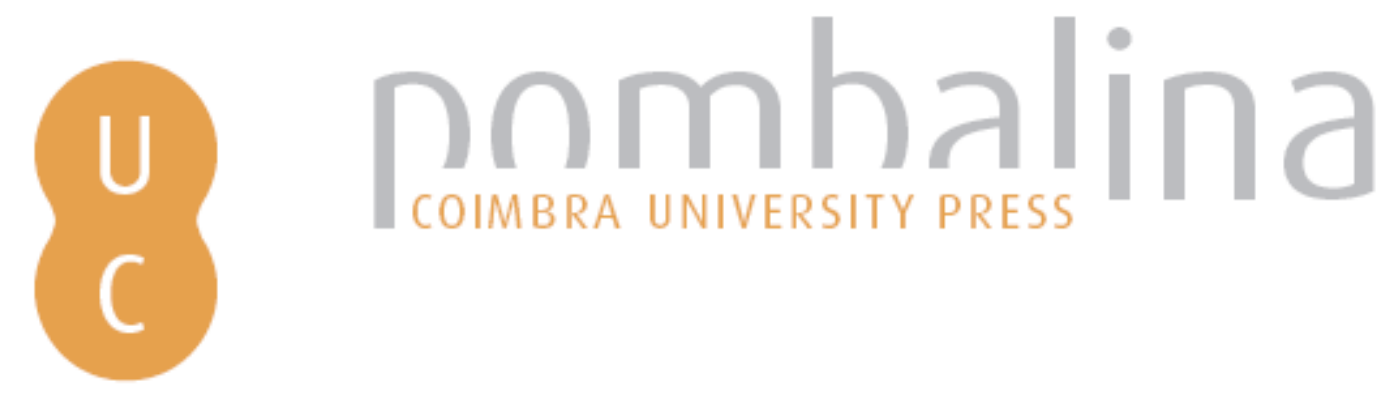

\title{
Physical growth and health status of mexican american youth: overview of past research by Robert M. Malina and fellows
}

\author{
Autor(es): Zavaleta, Antonio N. \\ Publicado por: Imprensa da Universidade de Coimbra \\ URL \\ persistente: URI:http://hdl.handle.net/10316.2/38545 \\ DOI: $\quad$ DOI:http://dx.doi.org/10.14195/978-989-26-0773-3_3 \\ Accessed : $\quad$ 26-Apr-2023 05:34:58
}

A navegação consulta e descarregamento dos títulos inseridos nas Bibliotecas Digitais UC Digitalis, UC Pombalina e UC Impactum, pressupõem a aceitação plena e sem reservas dos Termos e Condições de Uso destas Bibliotecas Digitais, disponíveis em https://digitalis.uc.pt/pt-pt/termos.

Conforme exposto nos referidos Termos e Condições de Uso, o descarregamento de títulos de acesso restrito requer uma licença válida de autorização devendo o utilizador aceder ao(s) documento(s) a partir de um endereço de IP da instituição detentora da supramencionada licença.

Ao utilizador é apenas permitido o descarregamento para uso pessoal, pelo que o emprego do(s) título(s) descarregado(s) para outro fim, designadamente comercial, carece de autorização do respetivo autor ou editor da obra.

Na medida em que todas as obras da UC Digitalis se encontram protegidas pelo Código do Direito de Autor e Direitos Conexos e demais legislação aplicável, toda a cópia, parcial ou total, deste documento, nos casos em que é legalmente admitida, deverá conter ou fazer-se acompanhar por este aviso.

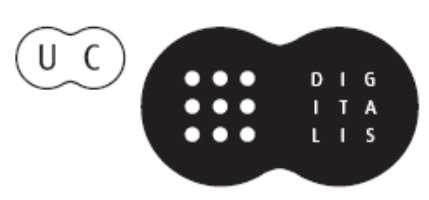




\section{GROWTH AND \\ MATURATION \\ IN HUMAN BIOLOGY \\ AND SPORTS}

FESTSCHRIFT HONORING ROBERT M. MALINA

BY FELLOWS AND COLLEAGUES

PETER TODD KATZMARZYK MANUEL J COELHO E SILVA

EDITORS 


\title{
PHYSICAL GROWTH AND HEALTH STATUS OF MEXICAN AMERICAN YOUTH: overview of past research by Robert $M$. Malina and fellows
}

\author{
Antonio N. Zavaleta
}

\section{INTRODUCTION}

Professor Robert M. Malina has dedicated his career to the study of human growth, development and physical performance. As such, he has always been keenly interested in the growth and development of children and the role that ethnic variation, migration and nutrition play in their ultimate adult stature, weight and associated dimensions and performance (Malina et al. 1970).

Professor Malina's career as an active physical anthropologist resulted in the incorporation of both field studies and students in his life's work. Beginning with United States-based population (Johnston et al. 1971), opportunity and professional inquiry led him to study the unique physical characteristics of the Zapotec native to Oaxaca in Mexico in the late 1960s (Malina et al. 1972). From the indigenous Zapotec of Latin America he investigated the mixed race or Mestizo/Ladino populations of Guatemalan Ladino children (Malina et al. 1974).

During the course of his career, professor Malina and his students returned to these field venues on several occasions, extending their original studies to significant longitudinal ones. In the case of the Zapotec, Malina's study continues to this day. His pattern of continuous study flows throughout his career and has proved significant in providing doctoral opportunities for several generations of students (1970-2010). Additionally, this pattern of collegial mentorship, combined with his research interests, has produced a cadre of graduates who continue to collaborate with Malina well into their careers. This pattern has suited all.

In the early 1970s, Professor Malina had recently arrived at University of Texas at Austin, having completed doctoral degrees in Kinesiology and Anthropology. As such, he enjoyed departmental appointments in both of the departments representing his disciplines.

\section{MEXICAN AMERICANS}

The University of Texas, while serving as the flagship university of a State with a significant Mexican American population, in fact, admitted very few African and Mexican Americans 
as undergraduates. Mexican American graduate students at University of Texas were even scarcer.

In 1971, Anthony N. Zavaleta, a Brownsville, Texas native took a course in human growth and development with Dr. Malina and that experience led him to a lifetime of collaboration and friendship. Malina's anthropology course changed Zavaleta's perspective on career and allowed him to fulfill a lifelong dream of studying the anthropology of the U.S.-Mexico border. Zavaleta completed the undergraduate degree in anthropology with honors and subsequently applied to the graduate program.

Zavaleta was admitted, conditionally, to the masters degree program, told by the graduate advisor that UT, "did not have a place for him and could not take a chance on him." Meaning, the message sent was that they could not take a chance on a Mexican American from the Lower Rio Grande Valley of Texas lowering their national standing. At that time, the UT anthropology doctoral program was ranked in the top ten in the country and readily admitted only top candidates nationally. "Admitting a Mexican American from the Rio Grande Valley of Texas was too much of a risk for the program to take," he was told by the graduate advisor.

Confident, and at the same time bolstered by the confidence and support of professor Malina, Zavaleta began his course work in physical anthropology, human growth and development, skeletal biology and human adaptation. Additionally in his studies he included a cultural focus on Latin America, Mexican Americans and the U.S.-Mexico border.

The combination of the courses, biological and cultural, led to his lifelong interests in the cultural aspects of health status and health care, which would some years later evolve into the sub-discipline today known as medical anthropology.

Zavaleta once encountered renowned medical anthropologist Arthur J. Rubel at a conference. Rubel and colleague, Madsen were among the first anthropologists to study Mexican American health status in the Lower Rio Grande Valley of Texas (Rubel 1966) (Madsen 1973). Armed with a Hogg Foundation for Mental Health grant in the early 1960s, the two pioneered a connection between physical and cultural anthropology; known today as alternative and complementary medicine. Professor Malina was always supportive of Zavaleta's interest in cultural and medical anthropology which they discussed often.

Through the work of Rubel and Madsen in south Texas, several next generation, native anthropologists were trained, including Joseph Spielberg-Benítez who retired from Michigan State University. 
Dr. Rubel pioneered the early development of the medical anthropology field, and when asked "how does one become a medical anthropologist?" Dr. Rubel replied to Zavaleta, "call yourself one."

In the middle 1970s, professor Malina was able to expand his work on the diversity of Latin American populations to Mexican Americans on the border. Serving as a mentor for Zavaleta, the initial interest and studies in the growth and development and health status of Mexican American children began with a master's thesis. (Zavaleta 1973).

By developing the confidence of school administrators at the Brownsville Independent School District in 1972, Zavaleta and Malina were able to conduct the first anthropometric study of Mexican American youth in a border town.

Completing his master's degree, and by proving himself to the anthropology faculty, Zavaleta was admitted to the doctoral program (Malina and Zavaleta 1976).

The close association of Malina and Zavaleta and their shared interest in the growth and development of Mexican American children, led to the study of their body composition and the completion of a doctoral dissertation (Zavaleta 1976).

The laboratory work on body composition was performed using the recentlycompleted underwater-weighing tank; constructed with the direction of Dr. Hugh Bonner. With the support and direction of professor Malina, the kinesiology department at UT was expanding into modern exercise physiology and Zavaleta's dissertation was the first to be completed using the now old method of complete body submersion for the determination of body composition.

This study performed by Zavaleta under the direction of Malina would further their interest in the nutritional and health status of Mexican Americans and its influence on growth and development in general (Malina 1987 a; Malina 1987 b; Malina 1987 c).

Malina mentored and guided a wide array of studies examining many topics and including many different graduate students from the initial Zavaleta study onward for more than 25 years. These studies examined both Mexican-American and Mexican children, including Mexican immigrants living in the United States (Hughes 1982).

Various studies on and about Mexican Americans began appearing in the literature in the 1920s, and Malina examined the historical literature with the publication of growth status of Mexican American children and youths: Historical and contemporary issues. While the initial anthropometric studies were conducted in the early part of the $20^{\text {th }}$ century, it was not until the work of Malina and Zavaleta that true growth studies were conducted on Mexican American children and connecting their status to health and 
nutritional status (Malina et al. 1986). Studies containing anthropometric data on Mexicans and Mexican Americans were sustained from 1920 through the 1990s. Through the work of Malina and Zavaleta they ultimately led to dramatic improvements in child-health status along the lower Texas-Mexico border (Malina and Zavaleta 1980) (Zavaleta and Malina 1980).

An historical overview of Mexican and Mexican American growth studies was published in homage to Mexican physical anthropologist Santiago Genovés for his 33 years of service to Mexican anthropology (Tapia 1990). In their contribution, Kobyliansky and Goldstein summarized the study of two generations of Mexican and Mexican American youth including the work of Malina and Zavaleta and compared the growth of children of Mexican parents in Mexico and in the United States as well as changes in physical traits with age of adults, the parents of the children (Kobyliansky and Goldstein 1990). In the same volume, Malina and Little examined body composition of young boys from rural Zapotec-speaking villages in Oaxaca, Mexico (Malina and Little 1990).

Credit must be given to the pioneers in physical anthropology who showed legitimate interest in Mexican American children beginning with Paschal and Sullivan in 1925 who studied the relationship between intelligence and growth; H. T. Manuel in 1934 who was principally interested in the education of Mexican Americans; Whitacre in 1939 took a more traditional approach while in 1943 Goldstein examined Mexican immigrant children and in 1952 Meridith and Goldstein examined growth and socioeconomic status of Mexican American Children (Malina and Zavaleta 1980).

In the period from the earliest Malina-Zavaleta studies, to the latest in the 1990s, and others have outlined the importance of establishing Mexican American baselines for determining health status (Mendoza 1991) (Zavaleta 2000). The Hispanic Health and Nutrition Survey in the 1980s played a role but little work has been completed to link Mexican American health to growth status (Troiano et al. 1995).

Meanwhile, Malina expanded his interests to include topics such as secular trends, age at menarche, growth spurts, nutritional status, human performance, immigrant status and intergenerational advances etc. Throughout the 1990s, Malina continued his work on Latin American populations expanding to Brazilians while further exploring opportunities with diverse European populations especially eastern European (Malina 1990). Malina continues his study of many and diverse aspects of the growth and development of Zapotec children. In the last 20 years, Malina's work as an active researcher, author and speaker is marked by its increasing universality in worldwide studies of human populations.

\section{WHAT HAPPENED NEXT?}

Zavaleta completed his doctoral degree at Texas in 1976 and returned to the Lower Rio Grande Valley. Zavaleta counts his years with Malina as the most significant in his life as they cemented the foundation for his professional career (Zavaleta 1989). While Malina 
and Zavaleta were not able to continue their studies of the growth and development of Mexican American children, Zavaleta utilized what he had learned from Malina and for the following quarter of a century made a positive impact upon the Mexican Americans of south Texas. Often, this took place in consultation with professor Malina (Zavaleta 2002).

Soon after returning to south Texas, and based upon the work of Malina and Zavaleta, a Health Needs Assessment Survey of Brownsville, Texas was performed (Zavaleta 1985). This study was the first-ever in south Texas and served as the basis for tens of millions of dollars in state and federal funds applied directly to improve the health status of the local population.

Another Malina student, William H. Muller at the University of Texas Health Science Center at Houston asked Zavaleta to join its South Texas Diabetes Research Project, which led to our early understanding of obesity and diabetes in Mexican American children (Muller et al. 1984) (Muller et al. 1984).

In his work with Malina, it became obvious that maternal and neonatal mortality rates in Cameron County, Texas were the highest in Texas. Further examination of this problem led to the creation of a Texas law regulating the practice of lay midwifery and ultimately saving hundreds of lives. This fact led to Zavaleta joining the board of directors of Su Clinica Familiar, a federally funded community and migrant-farmworker clinic in south Texas. Zavaleta served 20 years on the board and developed the clinic into a highly regarded system for the delivery of primary care as well as a birthing center for the indigent of south Texas.

Working with the University of Texas Medical Branch's Department of Pediatrics, a major multiple-year grant was awarded by the State of Texas for the development of a community oriented primary care facilities around the state. These projects were intended to deliver primary health care to poor Mexican Americans and other poor living in the colonias in and around Brownsville, Texas. The project treated many thousands and lasted 18 years until legislation changed directions (Zavaleta, et al. 1992).

In the 1990s Zavaleta began work with health-education professor Nell Gottlieb whom he had met through Malina, and the pair received a grant from the Texas Higher Education Coordinating Board to develop health-education material for the prevention of breast and cervical cancer among maquiladora (cross border factory) workers in Matamoros, Mexico (Gottlieb et al. 1996). Two Latina doctoral students were supported and trained through this project.

By the late 1990s, the COPRIMA project at UTMB had collected sufficient data under the supervision of professor Malina to conduct several studies which examined the relationship of Zinc to Mexican American growth status (Egger et al. 1999; Penland et al. 1999; Sandstead et al. 2000; Sandstead et al. 2008). 


\section{SUMMARY}

It is clear that any examination of Robert Malina finds a career full of diversity of investigation as well as support of students. This overview must also focus on the tangible projects that developed along our southern border during the last 35 years and to place those projects as points of light in Malina's list of accomplishments. It is with great respect and honor that I am able to point out these unparalleled accomplishments for the record of this great man's life. Professor Malina had total faith in what a Mexican American student from Brownsville, Texas could and would accomplish. Zavaleta's career varied somewhat from his colleagues (Zavaleta and Salinas 2009). However, through the work and vision of Malina, the lives of Mexican American children have and continue to be changed through the delivery of health care. Malina and Zavaleta set out to examine the health status of Mexican American youth through their growth status and those studies eventually led to the creation of tangible projects which operate today.

\section{REFERENCES}

Egger, N., Sandstead, H., Penland, J., Alcock, N., Plotkin, R., Rocco, C. Dayal, H. and Zavaleta, A., 1999, Zinc Supplementation Improves Growth in Mexican-American Children, FASEB J; 13: A246, Abstract 217.17. Presented as a poster at the Experimental Biology Conference 1999.

Johnston, F.E., Malina R.M. and Galbraith M.A., 197I, Height, weight, and age at menarche and the "critical weight" hypothesis. Science, I74, pp. I| 48 - I 449.

Goldstein, M.S., 1943, Demographic and bodily Changes in Descendants of Mexican Immigrants. Austin: University of Texas, Institute of Latin. American Studies

Gottlieb, N.H., Keogh, E.F., Zavaleta, A.N., Herrera, S., and Rodriguez, G., 1996, "Breast and cervical cancer screening among women working at the U.S.-Mexican border: Predictors of compliance," presented at Connecting the Efforts along the Border: The University of Texas System Fourth Biennial Symposium, South Padre Island, Texas, October 25, 1996.

Hughes, D., Malina, R.M., Zavaleta, A.N. and Johnston, F. E., 1982, Prediction of body composition in Mexican American boys 12-14 years of age, Abstract, American Journal of Physical Anthropology.

Kobyliansky and Goldstein, 1990, Changes in anthropometric traits of humans in the process of migration: Comparative analysis of two generations of Mexicans in Mexico and in the USA. In: Para Conocer al Hombre: Homenaje a Santiago Genovés por su 33 años de estudio, UNAM

Madsen, W., 1973, The Mexican Americans of South Texas, (New York: Holt, Rinehart and Winston, ).

Manuel, H.T., 1934, Physical Measurements of Mexican Children in American Schools, Society for Research in Child Development. 
Malina, R.M., Harper A.B. and Holman J.D., 1970, Growth status and performance relative to parental size. Research Quarterly, 4 I, pp. 503-509.

Malina, R.M., Selby H.A. and Swartz L.J., 1972, Estatura, peso y circunferencia del brazo en una muestra transversal de ninos Zapotecos de 6 a 14 anos. Anales de Antropologia, 9. pp. 143-155.

Malina, R.M., Habicht J-P, Yarbrough C., Martorell R., and Klein R.E., 1974, Skinfold thickness at seven sites in rural Guatemalan Ladino children, birth through seven years of age. Human Biology, 46, pp. 453-469.

Malina, R.M. and Zavaleta A.N., 1976, Androgyny of physique in female track and field athletes, Annals of Human Biology, 3, pp. 44I-446.

Malina, R.M. and Zavaleta A.N., 1980, Secular trend in the stature and weight of Mexican American children in Texas between 1930 and 1970. American Journal of Physical Anthropology 52, pp. 453-461.

Malina, R.M. and Zavaleta, A.N., 1980, Secular trend in the heights and weights of Mexican American children in Texas between 1930 and 1970, American Journal of Physical Anthropology 52, pp. 453-461.

Malina, R.M. et al. 1986 Growth status of Mexican American children and youths: Historical Trend and Contemporary Issues, American Journal of Physical Anthropology, 29, Supp 57, pp. 45-79

Malina, R.M., Zavaleta, A.N. and Little, B.B., 1986, Estimated overweight and obesity in Mexican American school children, International Journal of Obesity, I 0, pp. 483-49I.

Malina, R.M., Zavaleta, A.N. and Little, B.B., 1987, Body Size, Fatness and leanness of Mexican American children in Brownsville, Texas: Changes between 1972 and 1983. American Journal of Public Health, 77, pp. 573-577.

Malina, R.M., Zavaleta, A.N. and Little, B. B., 1987, Secular changes in the stature and weight of Mexican American school children in Brownsville, Texas, between 1928 and 1983. Human Biology, 59, pp. 509-522.

Malina, R.M., Brown, K.H. and Zavaleta, A.N., 1987, Relative lower extremity length in Mexican American and American Black and White youth, American Journal of Physical Anthropology, 72, pp. 89-94.

Malina, R.M., 1990. Growth of Latin American children: Socioeconomic, urban-rural and secular comparisons. Revista Brasileira de Ciencia e Movimento, 4, pp. 46-75.

Malina, R.M. and Little B.B., 1990, Estimated body composition of boys 9- 14 years of age from a rural Zapotec-speaking community in the Valley of Oaxaca. In Para Conocer al Hombre: Homenaje a Santiago Genovés as los 33 Años como Investigador en la UNAM, edited by Tapia, L.L., , (Mexico, DF: Universidad Nacional Autonoma de México), pp. 553-559.

Mendoza, F.S., et al., 1991, Selected measures of health status for Mexican American, mainland Puerto Rican, and Cuban American children, Journal of the American Medical Association, 265, pp. 227-232.

Muller, W.H., Joos, S.K., Ferrel, R.E., Zavaleta, A.N., Eichner, J. and Schull, W.J., 1984, Upper body fat patterning associated with Type II diabetes in Mexican Americans," Diabetes Abstracts, 32, p. 108. 
Muller, W.H., Joos, S.K., Hanis, C.L., Zavaleta, A.N., Eichner, J. and Schull, W. J., 1984, The Diabetes Alert Study: Growth, fatness, and fat patterning, adolescence through adulthood in Mexican Americans, American Journal of Physical Anthropology, 64, pp. 389-399.

Paschal and Sullivan, 1925, cited in Kobyliansky and Goldstein, Tapia, L., 1990, Para Conocer al Hombre: Homenaje a Santiago Genovés por su 33 años de estudio, UNAM.

Penland, J., Sandstead, H., Egger, N., Dayal, H., Alcock, N., Plotkin, R., Rocco, C. and Zavaleta, A., 1999, Zinc, Iron and Micronutrient Supplemention Effects On Cognitive and Psychomotor Function of Mexican-American School Children, FASEB J; I 3: pp. A92I, Abstract 683.4. Presented as a poster at the Experimental Biology Conference 1999.

Rubel, A.J., 1966, Across The Tracks: Mexican Americans in a Texas City, The University of Texas Press, Austin.

Sandstead, H., Penland, J., Prasad, A., Egger, N., Alcock, N., Carroll, R., Dayal, H., Zavaleta, A., Rocco, C., Plotkin, R., Milan, A. and Arambula, M., 2000, Zinc Deficiency in Mexican-American Children, presented as a poster at the $2^{\text {nd }}$ Meeting of the Association for Patient Oriented Research, Crystal City, Va.

Sandstead, H. et al., 2008, Zinc deficiency in Mexican American children: influence of zinc and other micronutrients on $\mathrm{T}$ cells, cytokines, and anti-inflammatory plasma proteins, American Journal of Clinical Nutrition, 88, pp. 1067-73.

Tapia, L., 1990, Para Conocer al Hombre: Homenaje a Santiago Genovés por su 33 años de estudio, (Mexico D.F.: UNAM).

Troiano, R.P. et al., 1995, Overweight prevalence and trends for children and adolescents, The National Health and Nutrition Examination Surveys, 1963 to 1991. Archives of Pediatrics and Adolescent Medicine. I49, pp. 1085-1091

Whitacre, 1939, As cited in Kobyliansky and Goldstein, Tapia, L., 1990, Para Conocer al Hombre: Homenaje a Santiago Genovés por su 33 años de estudio, UNAM.

Zavaleta, A.N., 1973, Growth of Mexican American school children in Brownsville, Texas, Abstract, American Journal of Physical Anthropology, 40, p. 157.

Zavaleta, A.N., 1976, Densitometric estimates of body composition in Mexican American boys, Abstract, American Journal of Physical Anthropology, 44, p. 216.

Zavaleta, A.N. and Malina, R.M., 1980, Growth, fatness, and leanness in Mexican American children, American Journal of Clinical Nutrition, 33, pp. 2008-2020.

Zavaleta, A.N., 198I, Variations in Hispanic health status, Research Bulletin, Hispanic Research Center, Fordham University, Vol. 4, pp. I-5.

Zavaleta, A.N., 1981, Federal assistance and Mexican American health status in Texas, Agenda: A Journal of Hispanic Issues, II , pp. 19-25.

Zavaleta, A.N. and Malina, R.M., 1982, Growth and body composition of Mexican American boys 9 through 14 years of age, American Journal of Physical Anthropology, 57, pp. 26I-27I.

Zavaleta, A.N., Coray, G. and Rubinstein, C., 1985, Health Needs Assessment Survey: A U.S. Mexico Border Community Case Study 1984-1985, published by The City of Brownsville, Texas. 
Zavaleta, A.N., Finkelstein, J., Rubinstein, C. and Rocco, C., 1989, Mexican American Health Status in a South Texas Colonia: Results from theCOPRIMA IPA-HMO Model 1986-1989, COPRIMA, Brownsville, Texas.

Zavaleta, A.N., Finkelstein, J.W., and Rocco, C.D., 1992, A modified community oriented primary care model for the delivery of migrant health care, Texas Journal of Rural Health, First Quarter.

Zavaleta, A.N., 2000, Do Cultural Factors Affect Hispanic Health Status, prepared for the UT-Health Science School of Public Health-Brownsville.

Zavaleta, A.N., April 2002, Hispanic/Latino Alternative, Complementary, Integrative, and Unconventional Health Practices and their Importance in the Allopathic Medical Model, Presented at a seminar at the University of Texas Health Sciences at San Antonio.

Zavaleta, A.N. and Salinas, A., 2009, Curandero Conversations: El Niño Fidencio, Shamanism and Healing Traditions of the Borderlands, Authorhouse, Indiana and The University of Texas at Brownsville, Brownsville, Texas. 